\title{
Evaluation of patients diagnosed with acute blunt aortic injury and their bedside plain chest radiography in the emergency department: A retrospective study
}

\author{
Funda Karbek Akarca, M.D., ${ }^{1}$ Tanzer Korkmaz, M.D., ${ }^{2}$ Celal Çınar, M.D., ${ }^{3}$ \\ Elif Dilek Çakal, M.D., ${ }^{1}$ Murat Ersel, M.D. ${ }^{1}$
}

\begin{abstract}
${ }^{1}$ Department of Emergency Medicine, Ege University Faculty of Medicine, Izmir-Turkey
${ }^{2}$ Department of Emergency Medicine, Izmir University Faculty of Medicine, Izmir-Turkey

${ }^{3}$ Department of Radiology, Ege University Faculty of Medicine, Izmir-Turkey
\end{abstract}

\begin{abstract}
BACKGROUND: The purpose of our study was to retrospectively evaluate traumatic aortic transection patients and their bedside plain chest radiographs for signs of aortic injury.

METHODS: Emergency department (ED) patients from a 5-year period with traumatic aortic transection who were over 18 years of age were included in the study. Demographic characteristics, mechanism of trauma, Revised Trauma Score, Glasgow Coma Score, vital signs, physical exam findings, laboratory parameters, length of stay in the ED, and patient outcomes were documented. Bedside plain chest radiograph images were interpreted by 2 emergency medicine specialists and I radiologist.
\end{abstract}

RESULTS: Thirty patients, mean age $45.87 \pm 16.14$ years (70\% male), were enrolled. Most common trauma mechanism was motor vehicle accident (53.3\%). Agreement rates between emergency medicine specialists and radiologist were found to be "excellent" and "substantial" in identifying mediastinal widening and multiple left sided rib fractures; and "fair" in identifying widened paraspinal line, and transthoracic vertebral fractures.

CONCLUSION: Though not completely reliable, bedside plain chest radiographs and physical examination findings may be useful in detecting aortic injury during primary survey when the patient is unstable and cannot be sent for chest computerized tomography. Appropriate further imaging studies should be carried out as appropriate based on patient's hemodynamic status.

Keywords: Aortic transection; imaging; reliability; trauma.

\section{INTRODUCTION}

Thoracic aortic injuries are responsible for a considerable portion of the deaths related to trauma. Though mostly due to blunt trauma mechanisms, thoracic aortic injuries may also result from penetrating and crushing types of trauma. ${ }^{[1]}$ Penetrating injuries are easily identified; however, diagnosis of blunt trauma may easily be missed. Traumatic energy arising from an impact is usually distributed throughout the entire

Address for correspondence: Funda Karbek Akarca, M.D. Ege Üniversitesi Tıp Fakültesi, Acil Tıp Anabilim Dalı, İzmir, Turkey Tel: +90 232 - 3902318 E-mail: fundakarbek@gmail.com

Qucik Response Code

Ulus Travma Acil Cerrahi Derg

2016;22(5):449-456

doi: $10.5505 /$ tjtes.2016.58524

Copyright 2016

TJTES mediastinal area. Crushing of the thoracic aorta between the sternum and the vertebral structures causes a sudden significant increase in intraluminal pressure. The proximal descending aorta is at greatest risk from shearing forces of sudden deceleration because it is fixed between the subclavian artery and ligamentum arteriosum. ${ }^{[2]}$ Acute blunt traumatic aortic injury (ABTAl) was first defined by an anatomist in 1557 to describe a victim who fell off a horse. ${ }^{[3]}$ Aortic transection is a rare lesion among major vessel injuries resulting from thoracic trauma. Incidence was calculated to be $0.3 \%$ in a series of pedestrian accident victims (5838 cases), $0.1 \%$ in a series of victims of fall from height ( 1163 cases), and $1.4 \%$ in a series of pelvic fractures (1450 cases). ${ }^{[4]}$ It has been reported that $80 \%$ of these patients do not survive to the emergency department (ED). ${ }^{[1,4]}$ If the adventitial layer of the aorta remains intact due to incomplete laceration of the ligamentum arteriosum, or if mediastinal hematoma develops, the patient may survive long enough to receive urgent definitive treatment. ${ }^{[5]}$ Timely diagnosis and treatment of aortic injury 
is crucial for the survival of a multitrauma patient admitted to the ED. History, physical exam, and bedside chest $x$-ray (CXR) provide useful clues leading to the diagnosis. However, one-third of patients with aortic injury due to blunt trauma do not show any external signs at physical examination. ${ }^{[6]}$ It is also mentioned in the literature that even though bedside CXR may reveal many signs pointing to major vessel injury, most of these findings lack sensitivity and specificity. ${ }^{[5,7]}$ Chest computerized tomography (CCT) is a frequently used imaging modality for trauma patients in the ED, with sensitivity and specificity rates nearing $100 \%{ }^{[4,5]}$

The aim of the present study was to retrospectively evaluate patients sent to the ED with ABTAI and compare the correlation between emergency medicine specialists and radiologists in interpreting bedside CXR images for possible aortic injury.

\section{MATERIALS AND METHODS}

\section{Study Design}

This retrospective cross-sectional study was performed in the ED of Ege University Hospital. University ethics committee approval was obtained prior to data collection. National laws and the World Medical Association Second Declaration of Helsinki were followed to protect patient rights and honor.

\section{Study Setting and Population}

All patients diagnosed as traumatic aortic transection in the ED of Ege University hospital between January I, 20II and December 3I, 2015 were retrospectively evaluated. Study population was composed of patients with International Statistical Classification of Diseases and Related Health Problems (ICD)-10 code 17I. Patients older than 18 years of age with traumatic aortic transection who had sufficient medical data were included in the study. Patients with penetrating trauma were excluded.

\section{Study Protocol}

Demographic values, trauma mechanism (fall from height, motorcycle accident, motor vehicle accident, pedestrian accident), Revised Trauma Score (RTS), Glasgow Coma Score (GCS), and vital signs (blood pressure [BP], heart rate [HR], respiratory rate, oxygen saturation) on arrival, physical examination findings (crackles, thoracic skin crepitation), laboratory parameters (white blood cell [WBC] count, hemoglobin [Hb], blood urea nitrogen [BUN], creatinine, liver function tests), length of stay in the ED, and clinical outcomes (admission, discharge, exitus) were recorded. Localization of aortic transection was recorded (aortic isthmus within $2 \mathrm{~cm}$ of the origin of the left subclavian artery, descending aorta, aortic arc or aortic isthmus). ${ }^{[8]}$ Surgical treatment methods used were noted (thoracic endovascular aortic repair [TEVAR], endovascular aortic repair [EVAR]). Aspartate aminotransferase (AST) levels $<35 \mathrm{U} / \mathrm{L}$ and alanine aminotransferase (ALT) levels $<45 \mathrm{U} / \mathrm{L}$ were considered normal. BUN, cre- atinine, WBC and $\mathrm{Hb}$ levels were measured as $\mathrm{mg} / \mathrm{dL}, \mathrm{mg} /$ $\mathrm{dL}, \mathrm{mm}^{3}$ and $\mathrm{g} / \mathrm{dL}$ respectively. The first bedside $\mathrm{CXR}$ and CCT images were digitally documented. CXR images were interpreted by 2 emergency medicine specialists and I radiologist, noting if several parameters were present or absent. Reviewing physicians were emergency medicine specialists with advanced degree and more than 10 years of experience in their specialty. Reviewers' interpretations were compared to reports of official radiologist, who had more than 5 years of experience in interventional radiology. Radiologist's interpretation was accepted as authoritative in bedside CXR image evaluation.

The following parameters were examined as aortic transection criteria on CXR: $:^{[7,9]}$

I. Mediastinal widening: More than $8 \mathrm{~cm}$ when supine (at the level of the left subclavian artery origin) on anteroposterior view of the chest or mediastinum to chest width ratio of $>0.25 .^{[9,10]}$

2. Downward displacement of the left mainstem bronchus: $>140^{\circ}$ from trachea

3. Indistinct or abnormal aortic contour

4. Deviation of trachea: To the right of the T3 or T4 spinous processes

5. Left apical capping

6. First and/or second rib fractures

7. Multiple left-sided rib fractures

8. Widened paraspinal line

9. Transthoracic vertebral fracture

10. Lung contusion

II. Left side hemothorax

The following parameters were examined for aortic transection on CCT images taken with third-generation CT scanner (Discovery CT 750 HD scanner; GE Healthcare, Little Chalfont, UK): Left first and/or second rib and left others rib fractures, scapula, sternum, clavicula and transthoracic vertebral fracture, left and any side hemothorax, pneumothorax, lung contusion, and mediastinal hematoma.

\section{Statistical Analysis}

SPSS software (version 17.0; SPSS Inc., Chicago, IL, USA) software was used for the statistical analyses. For measurement data conforming to normal distribution, arithmetic mean and standard deviation were calculated, and for data not conforming to normal distribution, median and $95 \%$ confidence intervals $(\mathrm{Cl})$ were obtained. For categorical data obtained by counting, the number and percentage were used.

\section{Reliability Assessment}

The kappa statistic was determined for each adverse effect to document inter-rater reliability and was reported as an overall mean with standard deviation. Kappa statistic of $<0.00$ was considered poor, $0.00-0.20$ was slight, $0.21-0.40$ was fair, $0.4 \mathrm{I}-0.60$ was moderate, $0.6 \mathrm{I}-0.80$ was substantial, and 


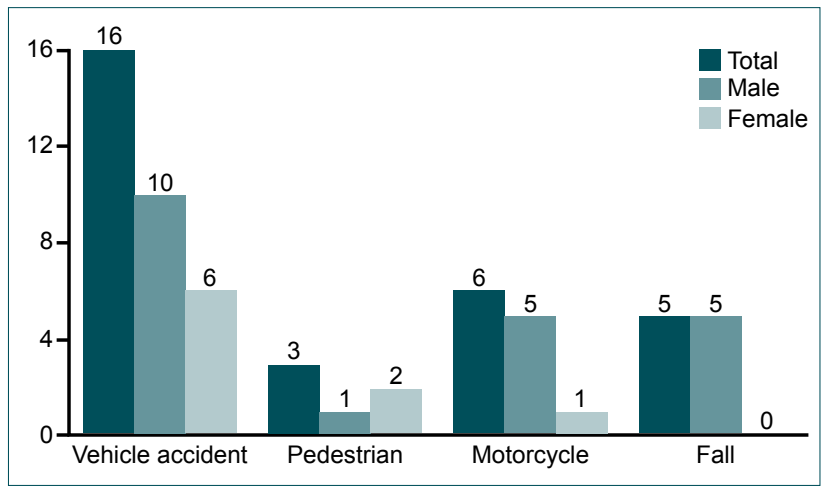

Figure 1. Distribution of patient age and gender according to trauma mechanism.

0.8I-I.00 was excellent agreement between physician raters. $\mathrm{P}$-value of less than 0.05 was considered significant.

\section{RESULTS}

Between January I, 20II and December 3I, 20I5, 309II of 60597 I ED patients were trauma patients. Of 50 I patients who were recorded as ICD code I7I, 30 (5.98\%) had aortic injury. The mean age of patients with ABTAI was $45.87 \pm 16.14$ years (range: 19-75 years), men predominated $(n=21)$, and $30 \%(n=99)$ were 55 years and older. The most common trauma mechanism was motor vehicle collision. One 21 -yearold male committed suicide by jumping from 2 nd floor, and a 19-year-old female committed suicide by jumping in front of a train. Distribution of patient age and gender according to trauma mechanism is provided in Figure I. RTS upon arrival, and hemodynamic and laboratory parameters are shown in Table I. RTS was 8 in 21 (70\%) cases, 7 in $5(16.7 \%)$ cases, and 6 in $2(6.7 \%)$ cases. GCS was 15 in $24(60 \%)$ cases, 13 in I case, and I 4 in 3 cases. GCS of 2 patients were undetermined. Arterial systolic BP was $<100 \mathrm{mmHg}$ in 9 cases and arterial diastolic BP was $<60 \mathrm{mmHg}$ in 12 cases. All cases with low systolic and diastolic arterial BP were tachycardic (pulse $>100 / \mathrm{min}$ ). Laboratory parameters revealed 24 cases (80\%) with elevated level of AST, 20 cases $(66.7 \%)$ showed elevated level of ALT, 22 cases (73.3\%) had high WBC level and 2 cases $(6.7 \%)$ had low WBC count. Physical exam recordings revealed crackles in 3 cases $(10 \%)$ and skin crepitation in 5 cases (16.7\%). CCT scan results revealed 8 cases $(26.7 \%)$ with subcutaneous emphysema. Of the CXRs, 29 (96.7\%) were found in the archives. Figure 2 shows examples of pathological ABTAI CXR images. Evaluation of bedside CXR by the radiologist and inter-rater reliability evaluation results are shown in Table 2. Agreement rates between emergency medicine specialists and radiologists were found to be excellent and substantial in identification of mediastinal widening and multiple left-sided rib fractures, and fair in identification of widened paraspinal line and transthoracic vertebral fractures. CCT results of all 30 cases were obtained and are shown in Table 3 and Figure 3. Of all cases, $40 \%$ had left lung contusion, $30 \%$ had mediastinal hematoma, and $33 \%$ had left first and/or second rib fracture. The most common localization for transection was the isthmus region of the aorta (Figure 4). Average length of stay in the ED was $21.95 \pm 29.95$ hours

Table I. Distribution of Glasgow Coma Score, Revised Trauma Score, vital signs, and laboratory parameters

\begin{tabular}{|c|c|c|}
\hline & Mean or median & $\begin{array}{c}\text { Range or } 95 \% \mathrm{Cl} \\
\text { Lower-upper bound }\end{array}$ \\
\hline Revised Trauma Score & $7.6 \pm 0.61$ & $6-8$ \\
\hline Glascow Coma Score* & $15 \pm 0.08$ & $14.6-15.0$ \\
\hline \multicolumn{3}{|l|}{ Vital signs } \\
\hline Arterial systolic blood pressure $(\mathrm{mmHg})$ & $121.67 \pm 23.88$ & $73-170$ \\
\hline Arterial diastolic blood pressure $(\mathrm{mmHg})$ & $72.18 \pm 22.33$ & $43-122$ \\
\hline Respiratory rate (min) & $27.85 \pm 7.02$ & $18-40$ \\
\hline Pulse rate $(\mathrm{min})$ & $107.44 \pm 22.24$ & $78-160$ \\
\hline $\mathrm{StO}_{2}(\%)$ & $93.29 \pm 4.20$ & $85-99 \%$ \\
\hline \multicolumn{3}{|l|}{ Laboratory parameters } \\
\hline Aspartate aminotransferase* (U/L) & $93.00 \pm 42.98$ & $75.7 I-25 I .80$ \\
\hline Alanine aminotransferase ${ }^{*}(\mathrm{U} / \mathrm{L})$ & $51.00 \pm 32.69$ & $52.32-186.29$ \\
\hline White blood cells $\left(\mathrm{mm}^{3}\right)$ & $15918.44 \pm 7422.09$ & $1209.00-3431.00$ \\
\hline Blood urea nitrogen (mg/dL) & $38.89 \pm 13.18$ & $19.00-74.00$ \\
\hline Creatinine $(\mathrm{mg} / \mathrm{dL})$ & $0.98 \pm 0.26$ & $0.59-1.43$ \\
\hline Hemoglobin (mg/dL) & $12.80 \pm 2.33$ & $8.00-16.70$ \\
\hline Hematocrit (\%) & $37.98 \pm 6.20$ & $25.00-50.00$ \\
\hline
\end{tabular}

*Data not conforming to normal distribution. 


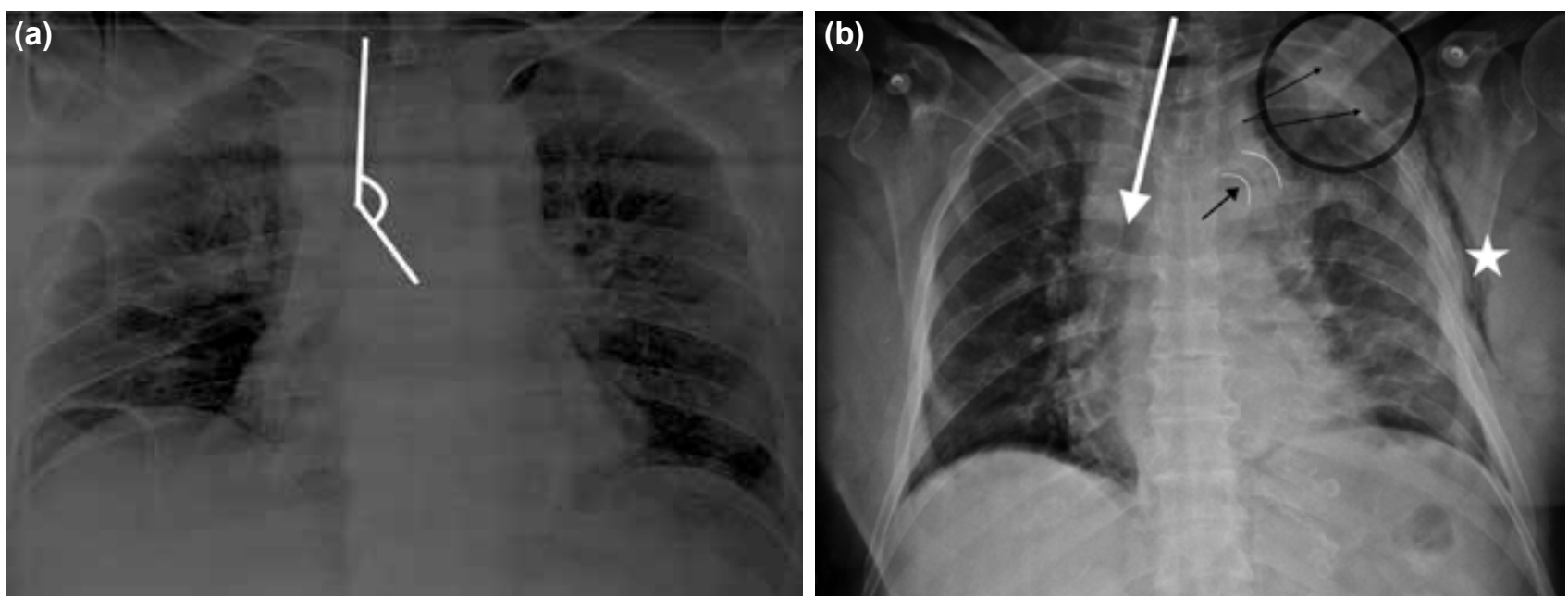

Figure 2. (a) Downward displacement of the left mainstem bronchus on chest x-ray and mediastinal widening, (b) white arrow indicates deviation of trachea; black arrow illustrates indistinct or abnormal aortic contour; magnifying glass shows first and second rib fractures; asterisks mark subcutaneous emphysema.

(range: I-137 hours), mean length of stay was $10.55 \pm 5.46$ The outcomes were as follows: 14 cases (46.7\%) were admithours (Cl\%: 10.78-33.12). ted to cardiovascular surgery ward, 6 cases $(20 \%)$ were ad-
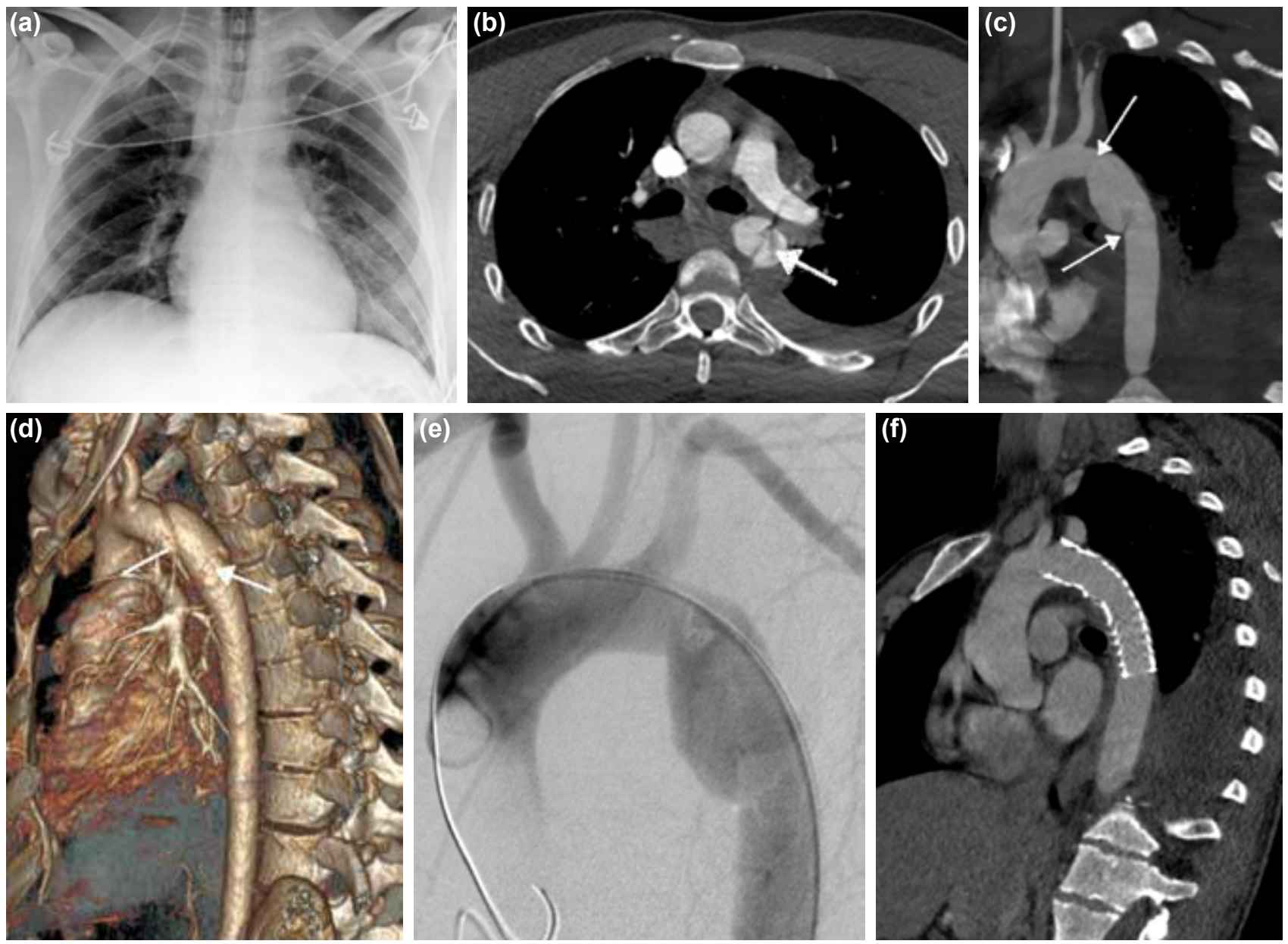

Figure 3. (a) Anteroposterior supine chest radiograph illustrating normal mediastinal widening in this patient, (b) contrast-enhanced axial computed tomography image of the chest with arrow indicating intimal flaps associated with traumatic aortic injury, (c) contrast-enhanced sagittal reformatted computed tomography image showing segmental transection (arrow), (d) CT scan with 3-dimensional reformation showing aortic transection (arrow), (e) oblique catheter angiogram image (arrow) from aortic isthmus, (f) computed tomography performed following endograft deployment. 
Table 2. Radiologist's evaluation of the bedside chest radiograph and indication of inter-rater reliability

\begin{tabular}{|c|c|c|c|c|c|c|c|}
\hline & \multirow{2}{*}{$\frac{\begin{array}{c}\text { Rad } \\
\text { evaluation }\end{array}}{n(\%)}$} & \multicolumn{2}{|c|}{ Rad/EMSI } & \multicolumn{2}{|c|}{ Rad/EMS2 } & \multicolumn{2}{|c|}{ EMSI/EMS2 } \\
\hline & & $\mathbf{k}^{*}$ & SE & $\mathbf{k}^{*}$ & SE & $\mathbf{k}^{*}$ & SE \\
\hline Widened mediastinum & $18(60.0)$ & 0.707 & 0.136 & 0.854 & 0.100 & 0.854 & 0.100 \\
\hline Downward displacement of the left mainstem bronchus & $4(13.3)$ & 0.669 & 0.171 & 0.606 & 0.205 & 0.583 & 0.184 \\
\hline Indistinct or abnormal aortic contour & $14(46.7)$ & 0.726 & 0.122 & 0.794 & 0.110 & 0.784 & 0.118 \\
\hline Left apical capping & $7(23.3)$ & 0.551 & 0.177 & 0.589 & 0.160 & 0.840 & 0.108 \\
\hline First and/or second rib fractures & $7(23.3)$ & 0.793 & 0.138 & 0.793 & 0.138 & 0.760 & 0.162 \\
\hline Multiple left-sided rib fractures & $9(3.0)$ & 0.854 & 0.100 & 0.707 & 0.136 & 0.854 & 0.100 \\
\hline Lung contusion & $7(23.3)$ & 0.847 & 0.104 & 0.765 & 0.127 & 0.765 & 0.127 \\
\hline Left side hemothorax & $3(10.0)$ & 0.722 & 0.128 & 0.862 & 0.094 & 0.861 & 0.094 \\
\hline Deviation of trachea & I (3.3) & 0.651 & 0.322 & 0.651 & 0.322 & 0.463 & 0.321 \\
\hline Widened paraspinal stripe & $6(20.0)$ & 0.392 & 0.134 & 0.392 & 0.134 & 0.862 & 0.094 \\
\hline Transthoracic vertebral fracture & $2(6.7)$ & 0.346 & 0.291 & 0.266 & 0.258 & 0.838 & 0.157 \\
\hline
\end{tabular}

EMSI-2: Emergency medicine specialists; $k^{*}$ : Kappa; rad: Radiologist; SE: Standard error.

$P$ value: Rad/EMSI and Rad/EMS2 statistically insignificant in transthoracic vertebral fracture $(p=0.29 I, P=0.124$ respectively) and other data statistically significant $(p<0.05)$.

Table 3. Findings on computed tomography of the chest

\begin{tabular}{lcc}
\hline Findings on computerized tomography of chest & $\mathbf{n}$ & $\%$ \\
\hline Left first and/or second rib fracture & 10 & 33.3 \\
Left other rib fracture & 11 & 36.7 \\
Bilateral first and/or second rib fracture & 2 & 6.7 \\
Bilateral other rib fracture & 5 & 16.7 \\
Scapula fracture & 4 & 13.3 \\
Sternum fracture & 2 & 6.7 \\
Clavicula fracture & 7 & 23.3 \\
Transthoracic vertebral fracture & 1 & 3.3 \\
Any side hemothorax & 13 & 43.3 \\
Left side hemothorax & 5 & 16.7 \\
Any side pneumothorax & 23 & 66.7 \\
Left side pneumothorax & 10 & 33.3 \\
Lung contusion & 21 & 70.0 \\
Mediastinal hematoma & 9 & 30.0 \\
\hline
\end{tabular}

mitted to anesthesiology and reanimation intensive care unit (ICU), 3 cases (10\%) were admitted to general surgery ward, 3 cases (10\%) were admitted to other wards, and 3 cases (10\%) were discharged from the ED due to regression of findings. During follow up, 5 of the admitted cases were transferred from wards to ICU, where they became exitus (at day 2, 7, 2I, $25,46)$. Three of these patients had vital signs of $B P<100 / 60$ $\mathrm{mmHg}$ and $\mathrm{HR}>100 \mathrm{bpm}$. Ten patients (33.3\%) underwent TEVAR surgery and I patient (3.3\%) underwent EVAR surgery; remaining patients were managed conservatively.

\section{DISCUSSION}

ABTAl is common in multitrauma patients and delay in its diagnosis causes significant mortality. In a case series where autopsies of 420 accidental deaths were evaluated, in nearly $10 \%$ of cases, the cause of death was found to be aortic injury. ${ }^{[9]}$ Other studies have found that motor vehicle accidents are responsible for $\mathbf{6 8 - 9 5 \%}$ of deaths due to aortic injury, and male patients are more common. ${ }^{[8,11]}$ Mosquera et al. reported mean age to be $4 \mathrm{I} .33$ years, and $26.3 \%$ of patients were over 55 years of age. ${ }^{[12]}$ Present study results correlated with literature findings.

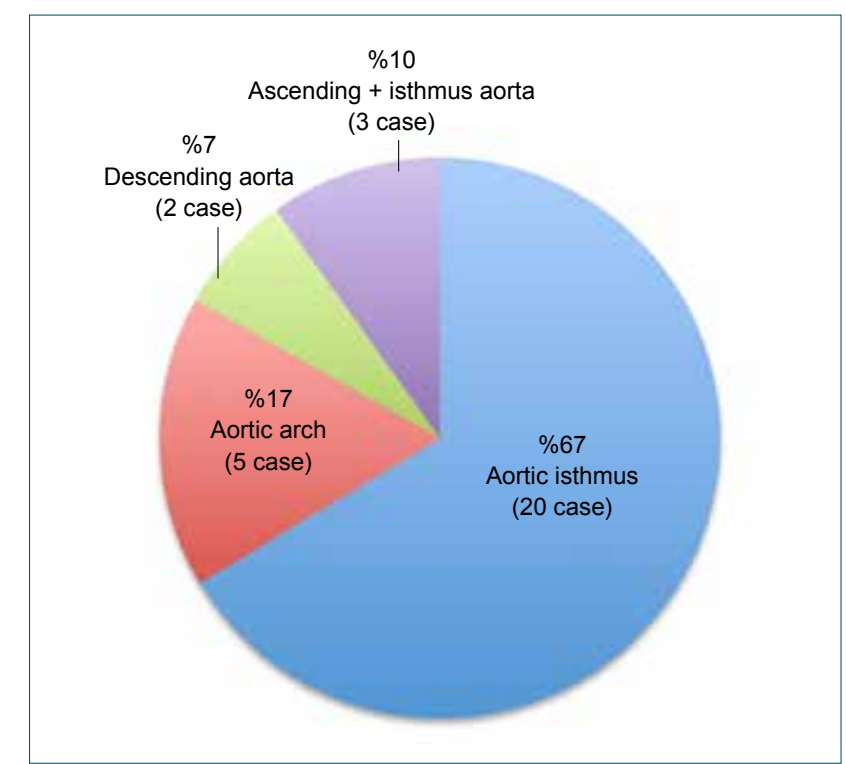

Figure 4. Patient injury locations. 
Rupture of the transected aorta in blunt thoracic trauma causes intrathoracic bleeding, which leads to resistant hypotension and a significant risk for mortality if not repaired in time. ${ }^{[5,12]}$ Generally, these patients do not possess significant physical examination findings; however, they are hemodynamically unstable, and in case of high suspicion, CXR provides clues for diagnosis. ${ }^{[5,6]}$ Blackmore et al. described 7 risk factors related to aortic injury including age $>50$ years, BP $<90 \mathrm{mmHg}$ and thoracic trauma. ${ }^{[13]}$ In a multicenter study, Mosquera et al. (82 aortic injuries from years 1980-2010) defined a traumatic aortic injury score (TRAINS) that included these criteria: widened mediastinum, hypotension, hemothorax, contusion, left scapular fracture. ${ }^{[12]}$ Mosquera et al. found mean RTS to be 5.98 and $34.2 \%$ of cases had GCS <9. ${ }^{[12]}$ Present study cases had similar characteristics; however, mean RTS and GCS were higher in this study group.

O'Conor stated that according to different studies, if aortic arch, descending aorta, aortopulmonary window, trachea, and left paraspinal space are normal, aortic rupture is $92 \%$ unlikely; and if nasogastric tube deviation does not exist and right paratracheal contour is clear, aortic rupture is $98 \%$ unlikely. It was said that if aortic arch and contour are normal and nasogastric tube or trachea deviation does not exist, aortic rupture can be ruled out. ${ }^{[9]}$ On bedside CXR, mediastinal widening has high sensitivity $(81-100 \%)$ and low specificity (34-60\%). ${ }^{[9,14]}$ According to ATLS guidelines, false positive and false negative findings seldom ( $1-13 \%)$ exist in CXR images. ${ }^{[14,15]}$ In the present study, $40 \%(n=12)$ of cases did not exhibit mediastinal widening. It should be kept in mind that although existence of mediastinal widening is significant, aortic injury cannot be ruled out in cases without mediastinal widening. In case of mediastinal hematoma, existence of indistinct aortic contour has high sensitivity but low specificity (53\% to $100 \%$, $21 \%$ to $55 \%$, respectively) at predicting aortic injury. ${ }^{[14]}$ In the current study, only 9 of the 14 cases with indistinct aortic contour on bedside CXR had mediastinal hematoma on CCT images. This difference may arise from the fact that most patients had the CXR taken in supine position using portable imaging equipment, rendering interpretation of CXR findings difficult because of poorer technical quality. It has been stated in previous literature that depression of the left mainstem bronchus, deviation of the trachea and nasogastric tube to the right of the T3 or T4 spinous processes in CXR images may indicate aortic injury. ${ }^{[14]}$ In the present study, of the 9 cases with mediastinal hematoma on CCT, only 4 cases had depression of the left mainstem bronchus and only I had deviation of the trachea on CXR. The first 3 ribs are protected by scapula, humerus, clavicle and their muscle groups. Injury to these bones and soft tissues may result in lung and major vessel injuries, increasing mortality by $35 \% .{ }^{[5]}$ In a study, only 4 of 50 cases with first and/or second rib fractures were accompanied by aortic injury (incidence $8 \%$ ). It was emphasized that rib fractures did not have negative predictive value for aortic injury. Mediastinal widening, trachea deviation, and loss of aortic contour are underlined as strong determinants for using advanced imaging techniques to look for aortic injury. ${ }^{[16]}$ In this study, according to the radiologist reports, left first and/or second rib fractures were seen in 7 cases $(23.3 \%)$ on CXR and 10 cases (33.3\%) on CCT. The soft tissue barrier around these ribs may be the reason bedside CXR images are blurry and harder to interpret. A study found that CCT is more sensitive than $C X R$ in diagnosing rib fractures. Bone scintigraphy spotted I86, CCT spotted 62 , and CXR identified 128 rib fractures. ${ }^{[17]}$ During secondary survey, patients with thoracic trauma should be evaluated for subcutaneous emphysema and fractures of rib, sternum, and scapula. Though not acutely lethal, these injuries may gradually lead to death. ${ }^{[5,12]}$ In the present study, 4 cases had scapula fracture and 2 cases had sternum fracture. Subcutaneous emphysema may arise from direct trauma or esophageal and airway trauma. In these cases, it should be kept in mind that positive pressure ventilation may lead to tension pneumothorax..$^{[5]}$ In hemodynamically unstable patients who need emergent intervention, physical examination and bedside CXR help spot serious injuries. In hemodynamically stable patients, CCT is an excellent tool for diagnosing aortic injury. ${ }^{[14]}$ It is not advised to use $C C T$ routinely in all blunt traumas, but in selected cases. ${ }^{[18]}$ After CCT, no further imaging is required for ABTAI and surgical endovascular repair should be done as soon as possible. ${ }^{[19]}$ Several reports have documented CCT as being more sensitive than conventional radiography at detecting blunt thoracic injuries..$^{[5,18,20]}$ In the 1980s and 1990s, CT was used together with angiography, but today, particularly multidetector-row CT has become the primary diagnostic tool. ${ }^{[14]}$ Allen and Blostein showed that CT was more efficient at detecting lung contusions than simultaneously taken CXR. It was stated that the contusion area determined with CT was 2-3 times larger than the area determined with CXR. ${ }^{[2]}$ Similarly, in the present study, 21 cases had contusion on CCT while only 7 cases had contusion on CXR. Considering these findings, it can be stated that bedside CXR is not completely reliable in determining the seriousness of the injury. Mediastinal hematoma spotted on CCT is of critical importance; however, it may be of venous origin as well as aortic origin. ${ }^{[14]}$ In the present study, all of the patients had aortic injury; however, $30 \%$ $(n=9)$ had mediastinal hematoma. In ABTAI, aortic tears are mostly seen in the isthmic area (79\%-96\%), especially within $2 \mathrm{~cm}$ of the subclavian artery. ${ }^{[4,8,22]}$ In the current study, $77 \%$ $(n=23)$ of cases had the injury in the isthmic area. In the literature, it is reported that $80-90 \%$ of cases with aortic injury died at the accident site, and $20 \%$ lasted longer than I hour. Of those, 30\% died in the first 6 hours, and $49 \%$ died within 24 hours. Of the remaining cases, $72 \%$ died within 8 days, and $90 \%$ of survivors died within the first 4 months. ${ }^{[23]}$ In a study of 24 cases, 15 received surgical repair; 2 (7\%) cases died in the acute period (in the ED and operating room) and 2 died in the long-term conservative period. ${ }^{[8]}$ In a comparison of a study conducted by the American Association for the Surgery of Trauma completed in 1997 (AASTI) and a similar study completed 10 years later (AAST2), mortality in patients who underwent open repair and EVAR was found to be $31 \%$ 
in AASTI and $13 \%$ in AAST2. ${ }^{20]}$ It is stated in the guidelines that $50 \%$ of the cases who survive to the hospital die within the first 24 hours. There are studies in the literature stating that $60 \%$ to $80 \%$ of cases that reach the hospital and receiving definitive therapy survive. ${ }^{[1,6,24]}$ In the present study, 5 patients (16.6\%) who received surgical repair (TEVAR, EVAR) died. None of our cases were open surgical repair. Though it is hard to comment upon long-term deaths since this study did not have long-term follow-up, it is possible to note that short-term mortality has gradually decreased along with the advancement of surgical techniques.

Bedside CXR still has critical importance even though advancements in technology have rendered $C T$ more available. For this reason, it is important to have a consensus in CXR interpretation to plan definitive treatment. In a study evaluating CXR images for mediastinal widening and aortic injury, Ho et al. stated that inter-rater reliability between 7 different radiologists was moderate (kappa=0.49). Ho et al. suggested that this might stem from probable deficiencies in medical education, and they concluded that mediastinal widening should no longer be used a predictor for aortic injury. ${ }^{[25]}$ In the present study, inter-rater reliability between the radiologist and the emergency medicine specialists was better (kappa=0.70-0.84), but this might be related to the fact that the interpreters were not blind in our study.

In conclusion, fast diagnosis and definitive treatment directly affect mortality and morbidity in cases of ABTAI. Primary survey physical examination findings and $C X R$ images may provide clues in running the first resuscitation. For secondary survey, hemodynamic stability of the patient and trauma mechanism may lead in determining appropriate further imaging techniques.

\section{Limitations}

This study does have limitations. First, it was conducted at a single institution and it includes the limitations inherent in any retrospective study. Second, because bedside CXR does not fulfill optimal requirements for an ideal CXR, image quality may be impaired, leading to false-positive results. Third, radiographs were presented to readers in an artificial research setting. For this reason, problems in recording or shooting may have affected image quality. Fourth, none of the readers were blind to the CXR; however, we believe that this limitation is acceptable, since our main aim in this study was not to define inter-rater reliability of diagnostic criteria.

\section{Conflict of interest: None declared.}

\section{REFERENCES}

1. Fox N, Schwartz D, Salazar JH, Haut ER, Dahm P, Black JH, et al. Evaluation and management of blunt traumatic aortic injury: a practice management guideline from the Eastern Association for the Surgery of Trauma. J Trauma Acute Care Surg 2015;78:136-46. Crossref
2. Chen MY, Miller PR, McLaughlin CA, Kortesis BG, Kavanagh PV, Dyer RB. The trend of using computed tomography in the detection of acute thoracic aortic and branch vessel injury after blunt thoracic trauma: single-center experience over 13 years. J Trauma 2004;56:783-5. Crossref

3. Mattox KL, Wall MJ Jr. Historical review of blunt injury to the thoracic aorta. Chest Surg Clin N Am 2000;10:167-82.

4. Demetriades D. Blunt thoracic aortic injuries: crossing the Rubicon.J Am Coll Surg 2012;214:247-59. Crossref

5. Ramenofsky M. Reconsidering the role of photoperiod in relation to effects of precipitation and food availability on spring departure of a migratory bird. Proc Biol Sci 2012;279:15-7. Crossref

6. Steenburg SD, Ravenel JG, Ikonomidis JS, Schönholz C, Reeves S. Acute traumatic aortic injury: imaging evaluation and management. Radiology 2008;248:748-62. Crossref

7. Woodring JH. The normal mediastinum in blunt traumatic rupture of the thoracic aorta and brachiocephalic arteries. J Emerg Med 1990;8:467-76.

8. Steenburg SD, Ravenel JG. Acute traumatic thoracic aortic injuries: experience with 64-MDCT. AJR Am J Roentgenol 2008;191:1564-9. Crossref

9. O'Conor CE. Diagnosing traumatic rupture of the thoracic aorta in the emergency department. Emerg Med J 2004;21:414-9.

10. Seltzer SE, D'Orsi C, Kirshner R, DeWeese JA. Traumatic aortic rupture: plain radiographic findings. AJR Am J Roentgenol 1981;137:10114. Crossref

11. Burkhart HM, Gomez GA, Jacobson LE, Pless JE, Broadie TA. Fatal blunt aortic injuries: a review of 242 autopsy cases. J Trauma 2001;50:113-5. Crossref

12. Mosquera VX, Marini M, Muñiz J, Asorey-Veiga V, Adrio-Nazar B, Boix R, et al. Traumatic aortic injury score (TRAINS): an easy and simple score for early detection of traumatic aortic injuries in major trauma patients with associated blunt chest trauma. Intensive Care Med 2012;38:1487-96. Crossref

13. Blackmore CC, Zweibel A, Mann FA. Determining risk of traumatic aortic injury: how to optimize imaging strategy. AJR Am J Roentgenol 2000;174:343-7. Crossref

14. Raptis CA, Hammer MM, Raman KG, Mellnick VM, Bhalla S. Acute traumatic aortic injury: practical considerations for the diagnostic radiologist. J Thorac Imaging 2015;30:202-13. Crossref

15. Fabian TC, Richardson JD, Croce MA, Smith JS Jr, Rodman G Jr, Kearney PA, et al. Prospective study of blunt aortic injury: Multicenter Trial of the American Association for the Surgery of Trauma. J Trauma 1997;42:374-80; discussion 380-3. Crossref

16. Woodring JH, Fried AM, Hatfield DR, Stevens RK, Todd EP. Fractures of first and second ribs: predictive value for arterial and bronchial injury. AJR Am J Roentgenol 1982;138:211-5. Crossref

17. Gunay SEI, Kurkcuoglu IC. The comparison of bone scintigraphy, computerized tomography and direct graphy in early period in blunt thoracic trauma. Tip Araștırmaları Dergisi 2013;11:4.

18. Blostein PA, Hodgman CG. Computed tomography of the chest in blunt thoracic trauma: results of a prospective study. J Trauma 1997;43:13-8.

19. Scaglione M, Pinto A, Pinto F, Romano L, Ragozzino A, Grassi R. Role of contrast-enhanced helical CT in the evaluation of acute thoracic aortic injuries after blunt chest trauma. Eur Radiol 2001;11:2444-8. Crossref

20. Demetriades D, Velmahos GC, Scalea TM, Jurkovich GJ, Karmy-Jones $\mathrm{R}$, Teixeira PG, et al. Diagnosis and treatment of blunt thoracic aortic injuries: changing perspectives. J Trauma 2008;64:1415-9. Crossref

21. Allen GS, Cox CS Jr. Pulmonary contusion in children: diagnosis and management. South Med J 1998;91:1099-106. Crossref

22. Macura KJ, Corl FM, Fishman EK, Bluemke DA. Pathogenesis in acute aortic syndromes: aortic aneurysm leak and rupture and traumatic aortic 
transection. AJR Am J Roentgenol 2003;181:303-7. Crossref

23. Holmes JH 4th, Bloch RD, Hall RA, Carter YM, Karmy-Jones RC. Natural history of traumatic rupture of the thoracic aorta managed nonoperatively: a longitudinal analysis. Ann Thorac Surg 2002;73:1149-54.

24. Orron DE, Porter DH, Kim D, Tortella B. False-positive aortography following blunt chest trauma: case report. Cardiovasc Intervent Radiol 1988;11:132-5. Crossref

25. Ho RT, Blackmore CC, Bloch RD, Hoffer EK, Mann FA, Stern EJ, et al. Can we rely on mediastinal widening on chest radiography to identify subjects with aortic injury? Emerg Radiol 2002;9:183-7.

\section{ORIJINAL ÇALIŞMA - ÖZET}

\section{Acil serviste akut künt travmatik aortik yaralanma tanısı alan olguların geriye dönük incelenmesi ve yatakbaşı akciğer grafi görüntülerinin değerlendirilmesi \\ Dr. Funda Karbek Akarca, ${ }^{1}$ Dr. Tanzer Korkmaz, ${ }^{2}$ Dr. Celal Çınar, ${ }^{3}$ Dr. Elif Dilek Çakal, ${ }^{1}$ Dr. Murat Ersel ${ }^{1}$}

${ }^{1}$ Ege Üniversitesi Tıp Fakültesi, Acil Tıp Anabilim Dalı, İzmir

${ }^{2}$ İzmir Üniversitesi Tıp Fakültesi, Acil Tıp Anabilim Dalı, İzmir

${ }^{3}$ Ege Üniversitesi Tıp Fakültesi, Radyoloji Bilim Dalı, İzmir

AMAÇ: Akut künt travmatik aortik yaralanması ile başvuran olguların geriye dönük olarak incelenmesi ve yatakbaşı akciğer grafisinde muhtemel aortik yaralanmaya ait bulgularının değerlendirilmesi amaçlandı.

GEREÇ VE YÖNTEM: Beş yıllık dönemde 18 yaş üstü akut travmatik aort transeksiyonu tanılı hastanın dosyaları geriye dönük olarak incelendi. Demografik özellikleri, olayın niteliği, revise travma skoru, Glaskow koma skalası, vital bulguları, fizik muayene bulguları, biyokimyasal parametreleri, acilde kalış süreleri, olguların takip sonucu ve yatakbaşı çekilen akciğer grafisi iki acil tıp uzmanı ve bir radyolog tarafından değerlendirildi.

BULGULAR: Çalışmaya 30 olgu alındı. Yaş ortalaması 45.87£ I6. I4 (\%70 erkek) ve en sık nedeni araçiçi trafik kazası (\%53.3) idi. Acil tıp uzmanları ve radyolog uyumu mediastinal genişlemesi ve sol seri kot kırıklarında 'mükemmel-kabul edilebilir', paraspinal hattın genişlemesi ve torasik vertebra kırığında 'zayıf' olarak tespit edildi.

TARTIŞMA: Akut künt travmatik aortik yaralanma primer bakıda fizik muayene ve akciğer grafisi resüsitasyon için fikir verebilir. İkincil bakı için hastanın hemodinamik stabilitesi ve yaralanma mekanizmaları da gözönüne alınarak uygun görüntüleme stratejileri belirlenmelidir.

Anahtar sözcükler: Aortik transeksiyon; görüntüleme; travma; uyumluluk.

Ulus Travma Acil Cerrahi Derg 2016;22(5):449-456 doi: 10.5505/tjtes.2016.58524 